\title{
Assessment of Nutritional Status of Adolescent Girls by Mid-Upper Arm Circumferences of Paschim Medinipur, India
}

\section{Kankana $\mathrm{De}^{\star}$}

Department of Anthropology, Vidyasagar University, India

\section{Introduction}

MUAC is the circumference of the left upper arm, measured at the mid-point between the tip of the shoulder and the tip of the elbow (olecranon process and the acromium). In children, MUAC is useful for the assessment of nutritional status. It is good at predicting mortality by iMUAC alone or MUAC for age; it also predicted death in children better than any other anthropometric indicator. Measurements of adult MUAC have long been known to reflect changes in adult body weight [1]. This advantage of MUAC was greatest when the period of follow-up was short. Ferro-Luzzi and James have proposed MUAC cut-off points for use in screening acute adult under nutrition. They are based on extrapolation from more normally nourished populations in developing countries, Under nutrition is outcome of in sufficient food intake and repeated infected disease, among total adolescent population $88 \%$ belong to developing country [2,3]. Adolescent of developing countries are at greater risk of undesirable consequences of under nutrition. In this study MUAc act as tool to study malnutrition. Roc curve in this study helps to determine malnutrition by MUAC.

\section{Methodology}

This is cross-sectional study done on 10-19 years adolescent girls of rural area; this study is done on 1009 girls. Some socio-economic data were taken by different anthropometry. Measurements are taken like Height by anthropometric rod and weight through weighing machine [4].

MUAc measurement help in calculate arm fat area and arm muscle circumference ,arm muscle area, MUAc is measure by inextensible scale after marking midpoint of upper arm between olecranon and acronomium process, height is measured by anthropometric rod nearest $0.5 \mathrm{~cm}$, Technical error of measurement is done to standardize data [5].

In this study table represents in that population mean is MUAc 21.71 (2.85), ANOVA shows that age wise increase in MUAC and they statistically significant (F-193.45) BMI are correlated with MUAC $(\mathrm{r}=0.350, \mathrm{p}=0.000)$ (Figure 1).

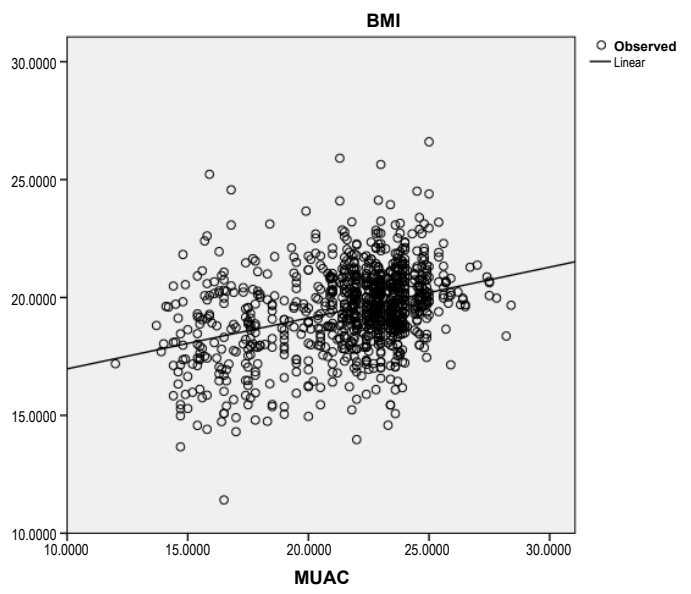

Figure 1: Linear graph shown relation between BMI (kg/sqm) and MUAC (cm)
Overall study represents that 404 among study population CED is below $5^{\text {th }}$ percentile, adolescent girls of 10 years age are all underweight on basis on MUAc (Tables 1-3). 76 girls of 11 years are suffering from under nutrient (Table 4). Table 4 had shown that mean MUAc 21.71 (2.58), mean BMI is $19.50 \mathrm{~kg} / \mathrm{sqm}$ (3.09) [6,7].

\begin{tabular}{|c|c|c|}
\hline \multicolumn{2}{|c|}{ Mean } & 21.714 \\
\hline \multicolumn{2}{|c|}{ Median } & 22.60 \\
\hline \multicolumn{3}{|c|}{ Std. Deviation } \\
\multirow{3}{*}{ Percentiles } & 50 & 2.85 \\
\cline { 2 - 3 } & 75 & 22.60 \\
\cline { 2 - 3 } & 95 & 23.60 \\
\hline
\end{tabular}

Table 1: Mean SD of MuAc of study population.

\begin{tabular}{|c|c|c|c|c|c|}
\hline \multicolumn{2}{|c|}{ Types of CED } & Frequency & Percent & Valid Percent & Cumulative Percent \\
\hline 1.00 & 404 & 40.0 & 40.0 & 40.0 \\
\hline 2.00 & 605 & 60.0 & 60.0 & 100.0 \\
\hline Total & 1009 & 100.0 & 100.0 & \\
\hline
\end{tabular}

Table 2: Frequency of CED of adolescent girls.

\begin{tabular}{|c|c|c|c|}
\hline \multirow{2}{*}{ Age (years) } & \multicolumn{2}{|c|}{ MUAc (cm) } & Total \\
\hline 10 & $\mathbf{1}$ & $\mathbf{2}$ & \\
\hline 11 & 100 & 0 & 100 \\
\hline 12 & 76 & 24 & 100 \\
\hline 13 & 61 & 39 & 100 \\
\hline 14 & 53 & 47 & 100 \\
\hline 15 & 35 & 65 & 100 \\
\hline 16 & 25 & 75 & 100 \\
\hline 17 & 17 & 83 & 100 \\
\hline 18 & 17 & 83 & 100 \\
\hline 19 & 17 & 83 & 100 \\
\hline
\end{tabular}

Table 3: Age wise comparison of MUAc.

\begin{tabular}{|c|c|c|}
\hline & MUAc (cm) & BMI (kg/sqm) \\
\hline \multirow{2}{*}{ Total no. } & 1009 & 1009 \\
\hline Mean & & \\
\hline Std. Deviation & 21.71 & 19.50 \\
\hline Variance & 2.85 & 1.75 \\
\hline
\end{tabular}

Table 4: Mean, SD of BMI, MUAc of adolescent girls

*Corresponding author: Kankana De, Department of Anthropology, Vidyasagar University, Medinipur, West Bengal 721101, India, Tel: +919474714273, E-mail: dekankana@gmail.com

Received October 07, 2016; Accepted October 25, 2016; Published November 01,2016

Citation: De K (2016) Assessment of Nutritional Status of Adolescent Girls by MidUpper Arm Circumferences of Paschim Medinipur, India. Primary Health Care 6 : 242. doi:10.4172/2167-1079.1000242

Copyright: ( 2016 De K. This is an open-access article distributed under the terms of the Creative Commons Attribution License, which permits unrestricted use, distribution, and reproduction in any medium, provided the original author and source are credited. 
BMI is decreased significantly $(\mathrm{F}=243.0 ; \mathrm{p}<0.001)$ from the highest MUAC group $\left(22.5 \mathrm{~kg} / \mathrm{m}^{2}\right)$ to the lowest one $\left(17.1 \mathrm{~kg} / \mathrm{m}^{2}\right)$. Overall prevalence of CED $\left(\mathrm{BMI}<18.5 \mathrm{~kg} / \mathrm{m}^{2}\right)$. MUAc is a measure of both energy deficiency in adult and children, and is a useful index of the efficacy of the nutritional therapy in PEM and obesity. The measurement of MUAC can be regarded as a screening method for underweight, normally assessed from BMI to identify the preferential loss of peripheral tissue stores of fat and protein [8]. The MUAc value of a well-nourished child is above $13.5 \mathrm{~cm}$, between $12 \mathrm{~cm}$ and $13.5 \mathrm{~cm}$ indicates malnutrition and below 12 indicates more severe malnutrition (WHO, 1995). Out of 50 subjects, 76\% (38) were having MUAC value $<23 \mathrm{~cm}$, which shows an inverse relation between MUAC and clinical staging (Table 5). The mean age of patients with MUAC value $<23 \mathrm{~cm}$ was 36.5 years, CED based on BMI in criteria $<18.52$ shows 94.03 specificity npv is $90 \mathrm{PPV}$ is 9.7 represented in Table 5. Receiver operating curve characteristic Table 6 represents that area under the ROC curve is 0.604 which is significant at $<0.05$ in CED analysis based on BMI (Tables 6-8). Table 7 shows results of receiver operating analysis

\begin{tabular}{|c|c|c|c|c|c|c|c|}
\hline Criterion & Sensitivity & $\mathbf{9 5 \%}$ Cl & Specificity & $\mathbf{9 5 \%}$ Cl & +PV & $\mathbf{9 5 \%}$ Cl & -PV \\
\hline$\leq 18.5225$ & 5.77 & $1.2-15.9$ & 94.03 & $85.4-98.3$ & 9.7 & $0.06-52.7$ & 90 \\
\hline$\leq 18.5348$ & 7.69 & $2.1-18.5$ & 94.03 & $85.4-98.3$ & 12.5 & $0.2-54.9$ & 90.2 \\
\hline$\leq 18.6214$ & 9.62 & $3.2-21.0$ & 94.03 & $85.4-98.3$ & 15.2 & $0.6-57.0$ & 90.4 \\
\hline$\leq 18.6412$ & 11.54 & $4.4-23.4$ & 94.03 & $85.4-98.3$ & 17.7 & $1.1-58.8$ & 90.5 \\
\hline$\leq 18.6558$ & 11.54 & $4.4-23.4$ & 92.54 & $83.4-97.5$ & 14.7 & $0.9-51.3$ & 90.4 \\
\hline
\end{tabular}

Table 5: Results of receiver operating curve characteristic of CED

\begin{tabular}{|c|c|}
\hline Area under the ROC curve (AUC) & 0.604 \\
\hline Standard Error a & 0.0523 \\
\hline $95 \%$ Confidence interval $^{b}$ & 0.510 to 0.692 \\
\hline z statistic & 1.988 \\
\hline Significance level P (Area=0.5) & 0.0468 \\
\hline
\end{tabular}

Table 6: Area under the ROC curve (AUC).

\begin{tabular}{|c|c|c|c|c|c|c|c|}
\hline Criterion & Sensitivity & $\mathbf{9 5 \% C I}$ & Specificity & & +PV & $\mathbf{9 5 \%}$ & $\mathbf{- P V}$ \\
\hline$>22.9$ & 53.64 & $49.6-57.7$ & 79.95 & $75.7-83.7$ & 80 & $75.8-83.8$ & 53.6 \\
\hline$>23$ & 47.52 & $43.5-51.6$ & 83.42 & $79.4-86.9$ & 81.1 & $76.6-85.0$ & 51.5 \\
\hline$>23.1$ & 46.85 & $42.8-50.9$ & 83.42 & $79.4-86.9$ & 80.9 & $76.3-84.8$ & 51.2 \\
\hline$>23.2$ & 46.03 & $42.0-50.1$ & 83.42 & $79.4-86.9$ & 80.6 & $76.0-84.6$ & 50.8 \\
\hline$>23.3$ & 45.36 & $41.3-49.4$ & 84.41 & $80.5-87.8$ & 81.3 & $76.7-85.3$ & 50.8 \\
\hline$>23.4$ & 41.23 & $37.3-45.3$ & 87.13 & $83.5-90.2$ & 82.7 & $78.0-86.8$ & 49.8 \\
\hline$>23.5$ & 37.25 & $33.4-41.2$ & 88.12 & $84.6-91.1$ & 82.4 & $77.4-86.7$ & 48.4 \\
\hline$>23.6$ & 34.44 & $30.6-38.4$ & 90.1 & $86.8-92.8$ & 83.9 & $78.7-88.2$ & 47.9 \\
\hline$>23.7$ & 29.64 & $26.0-33.5$ & 91.34 & $88.2-93.9$ & 83.6 & $78.0-88.3$ & 46.5 \\
\hline$>23.8$ & 26.82 & $23.3-30.5$ & 91.83 & $88.7-94.3$ & 83.1 & $77.1-88.1$ & 45.6 \\
\hline$>23.9$ & 21.85 & $18.6-25.4$ & 93.32 & $90.4-95.5$ & 83 & $76.3-88.5$ & 44.4 \\
\hline
\end{tabular}

Table 7: Results of receiver operating curve characteristic of MUAC.

\begin{tabular}{|c|c|c|c|c|c|c|c|c|}
\hline & \multirow{2}{*}{ Model } & \multicolumn{2}{|c|}{$\begin{array}{l}\text { Unstandardized } \\
\text { Coefficients }\end{array}$} & \multirow{2}{*}{\begin{tabular}{|c|}
$\begin{array}{c}\text { Standardized } \\
\text { Coefficients }\end{array}$ \\
Beta
\end{tabular}} & \multirow{2}{*}{$\mathbf{t}$} & \multirow{2}{*}{ Sig. } & \multicolumn{2}{|c|}{$\begin{array}{c}95.0 \% \\
\text { Confidence } \\
\text { Interval for B }\end{array}$} \\
\hline & & B & Std. Error & & & & $\begin{array}{l}\text { Lower } \\
\text { Bound }\end{array}$ & $\begin{array}{l}\text { Upper } \\
\text { Bound }\end{array}$ \\
\hline \multirow{2}{*}{1} & (Constant) & 14.816 & 0.399 & & 37.126 & .000 & 14.033 & 15.599 \\
\hline & MUAC & 0.216 & 0.018 & 0.350 & 11.839 & .000 & 0.180 & 0.251 \\
\hline \multicolumn{9}{|c|}{ a. Dependent Variable: BMI } \\
\hline
\end{tabular}

Table 8: Linear regression show relation of BMI and MUAC. curve characteristic of criteria <22.9 MUAc sensitivity 53.4 specificity PPV 79.9 and PPV is 80 and NPV 53.6. Table 6 represents that $<18.64$ is best indicator for analysis CED based on MUAC where specificity and sensitivity is highest.

\section{Discussion}

In this study, it shows in respect to MUAc present study population is under nutrient, MUAc have correlation with BMI that means higher MUAC have this present study represents that $40 \%$ girls are under nutrient, $24 \%$ girls are under nutrient is respect to BMI. MUAc and BMI relation show it significant regression relation.

\section{References}

1. De K, Das S, Bose K, Chakraborty R (2011) Nutritional Status Of Rural Girls Aged 10-18 Years Of Salboni, Paschim Medinipur, West Bengal, India. Asian Journal Of Biological Science And Life Sciences.

2. Chakraborty R, Bose K, Bisai S (2009) Use of mid upper arm circumference as measure $f$ nutritional status and its relationship with self-reported morbidity among male slum dwellers of Kolkata, India. Appetite and nutritional assessment, New York, pp: 375-388.

3. Jeyakumar A, Ghugre P, Gadhave S (2013) Mid-upper-arm circumference (MUAC) as a Simple measure to assess the nutritional status of adolescent girls as compared with BMI. Childhood Obesity and Nutrition.

4. Roy NC (2000) Use of mid upper arm circumference for evaluation of Nutritional status of children and for high risk group for malnutrition in rural Bangladesh. $\mathrm{J}$ HEALTH POPULL Nutr 18:171-180.

5. Biswas S, Bose K, Mukhopadhay A, Bhadra M (2010) Mid-upper arm circumference based under nutrition among Bengali children of Chapra, West Bengal, India. Iran J Pediatr 20: 63-68.

6. Singh PK, Mukherjee B (2015) Assessment of nutritional status by mid upper arm circumference (MUAC) among rural children of Katihar district in Kosi region of Bihar. Journal of Evolution of Medical and Dental Sciences 4: 3823 3828

7. Qureshi MA, Qureshi IA, Syed A, Kokku SB (2014) Assessing the prevalence of malnutrition in tribal children using MUAC as a screening tool [version 1 referees: 1 approved, 1 approved with reservations]. F1000 Research 3: 250.

8. Ferro-Luzzi A, James WP (1996) Adult malnutrition: Simple assessment techniques for use in emergencies $\mathrm{Br} \mathrm{J}$ Nutr 75: 3-10. 